Provided for non-commercial research and education use. Not for reproduction, distribution or commercial use.

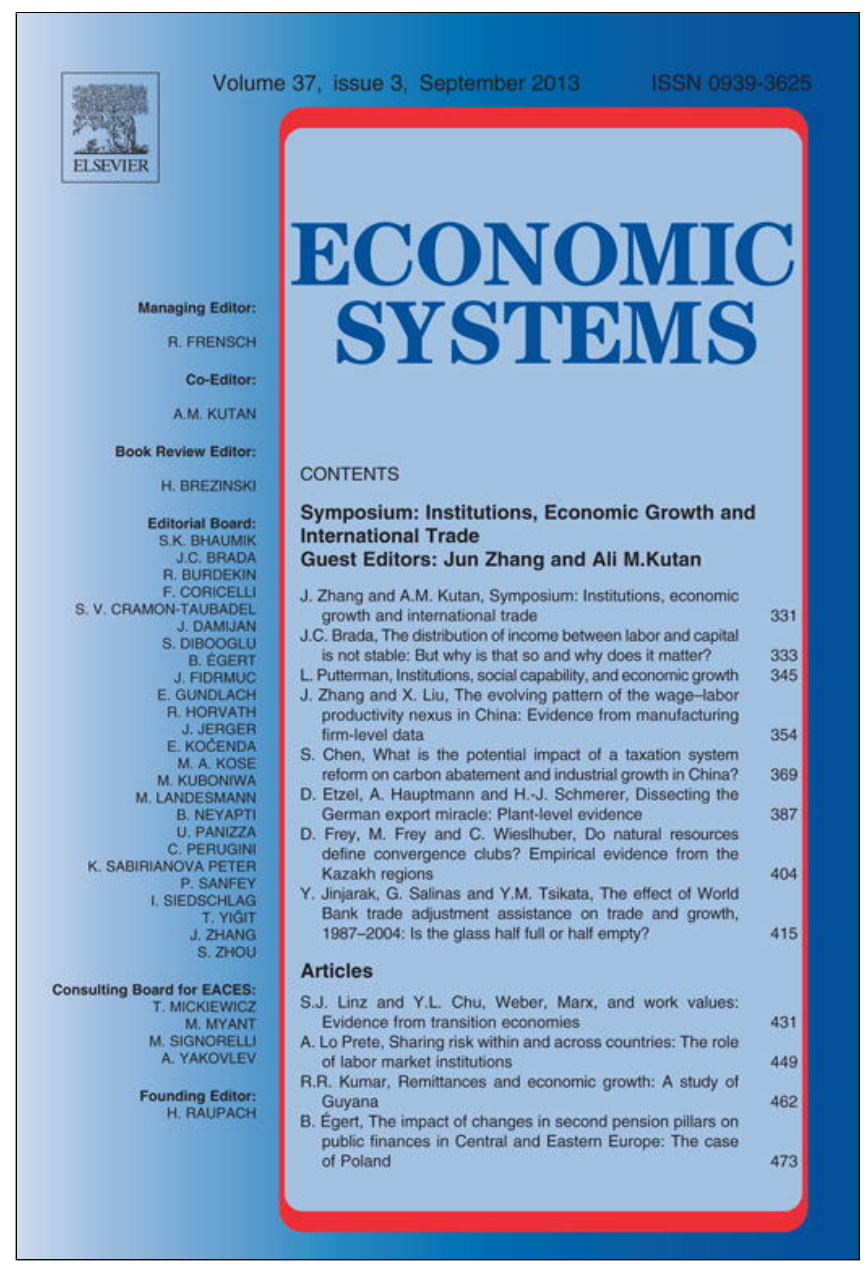

This article appeared in a journal published by Elsevier. The attached copy is furnished to the author for internal non-commercial research and education use, including for instruction at the authors institution and sharing with colleagues.

Other uses, including reproduction and distribution, or selling or licensing copies, or posting to personal, institutional or third party websites are prohibited.

In most cases authors are permitted to post their version of the article (e.g. in Word or Tex form) to their personal website or institutional repository. Authors requiring further information regarding Elsevier's archiving and manuscript policies are encouraged to visit:

http://www.elsevier.com/authorsrights 


\title{
The effect of World Bank trade adjustment assistance on trade and growth, 1987-2004: Is the glass half full or half empty?
}

\author{
Yothin Jinjarak $^{\mathrm{a}, *}$, Gonzalo Salinas ${ }^{\mathrm{b}}$, Yvonne M. Tsikata ${ }^{\mathrm{c}}$ \\ a DeFiMS, School of Oriental and African Studies, University of London, WC1H OXG, UK \\ ${ }^{\mathrm{b}}$ African Department, International Monetary Fund, Washington, D.C. 20431, USA \\ ${ }^{\mathrm{c}}$ Poverty Reduction and Economic Management, World Bank, Washington, D.C. 20433, USA
}

\section{A R T I C L E I N F O}

\section{Article history:}

Received 7 October 2012

Received in revised form 1 May 2013

Accepted 4 May 2013

JEL classification:

E02

F13

$\mathrm{O} 24$

Keywords:

International financial institutions

Trade reform

Sample selection

\begin{abstract}
A B S T R A C T
This paper studies the association between trade reform, growth, and trade adjustment assistance in a sample of developing countries that underwent trade reforms during 1987-2004. Our analysis explicitly differentiates between a group of countries that received trade adjustment loans from the World Bank and a nonrecipient group. The results suggest that trade adjustment assistance is positively associated with economic growth after trade reform in the medium to long run. In comparison to a prereform period and to the non-recipient group, the recipient countries registered 0.2 percent higher growth of real GDP per capita, 5.0 percent higher import growth, and 2.5 percent higher export growth over a period of three to five years after trade reform.

(c) 2013 Elsevier B.V. All rights reserved.
\end{abstract}

\section{Introduction}

The late 1980s to early 2000s constituted a period of significant trade reform initiatives across the developing world. During these years, protectionist policies and import substitution-led strategies were abandoned as the developing countries sought to achieve more sustainable paths to development and greater economic integration into the global trading system. For some countries,

\footnotetext{
* Corresponding author. Tel.: +44 02078984352; fax: +44 02078984487.

E-mail addresses: yj5@soas.ac.uk (Y. Jinjarak), gsalinas@imf.org (G. Salinas), ytsikata@worldbank.org (Y.M. Tsikata).
} 
the process of trade reforms was undertaken without trade adjustment assistance and external assistance. For many, however, trade reforms were aided by international organizations, both technically and financially. This paper studies economic performance after trade reforms and the role of trade adjustment lending extended by the World Bank to a large number of developing countries from 1987 to 2004.

By focusing on this episode of trade reforms and trade adjustment loans, our work provides a historical account and contributes to a strand of the literature that studies the effect of trade adjustment assistance on economic reform. Recent works, notably Cadot et al. (2011), point out that the challenges facing any evaluation framework on the effectiveness of trade adjustment assistance are due to the lack of consensus on suitable criteria for distributing the aid for trade effectively. Any evaluation study is further complicated by the wide variation in the quality of data and cross-country empirical specifications. ${ }^{1}$ Against these backdrops, a recurring theme in the literature is to search for answers to the following two empirical questions: first, were economic reforms beneficial to the countries that undertook them, i.e. in terms of macroeconomic outcomes, productivity, and GDP growth; and, second, did the trade adjustment assistance have favorable value-added impacts that helped improve the economic outcomes significantly in the aid-recipient countries?

Trade has traditionally been viewed as a driving factor of external balance and an engine of growth through improved resource allocation, stronger incentives for adaptation and innovation, cheaper capital goods, and higher foreign direct investment flows associated with new trade opportunities. While it is believed that countries grow more rapidly by abandoning a long-term autarkic approach, existing evidence on the association between trade reforms and economic performance have been inconclusive. As trade remains important to the overall development strategy in the developing countries, this empirical uncertainty has generated a long-standing debate on whether there is any link between trade reform and economic growth, as well as any potential role of trade adjustment assistance and external intervention.

In the past, well-known studies such as those by Sachs and Warner (1995), Krueger (1998), Edwards (1998), Frankel and Romer (1999), Dollar and Kraay (2004) and Berg et al. (2012) suggest that more open countries tend to grow faster. In the literature, openness to trade, or trade intensity, is typically defined as the ratio of gross trade (imports plus exports) relative to GDP. However, as Looi Kee et al. (2009) and Collier et al. (1999) argue, the trade intensity index may not be entirely appropriate as an indicator of the trade policy stance. The index may instead reflect an increase in aid flows or an improvement in terms of trade rather than the extent of trade reforms. Further, Rodriguez and Rodrik (2000) point out methodological problems with the empirical strategies thus far undertaken to establish the relation between trade reform and economic growth, particularly the use of the openness dummy variable proposed by Sachs and Warner (1995) and later by Wacziarg and Welch (2008). This is because in practice the openness dummy variable that aims to characterize the restrictiveness of a trade policy regime is often correlated with other measures of poor economic performance. To improve upon the restrictiveness measure of a trade regime, Wacziarg and Welch (2008) attempt to identify years when non-reversed trade liberalization programs were launched. Applying this new indicator together, they find that output, investment, and openness increase significantly after trade liberalization.

Clearly, a proper identification of the years in which trade reforms have taken place allows for a more assertive conclusion about the impact of trade reforms on output growth and other variables of general interests, including both export and import growth. For example, using twenty-two episodes of trade liberalization, Santos-Paulino and Thirlwall (2004) find that after controlling for several variables such as changes in world demand and the real effective exchange rate, trade liberalization still has a large positive impact on both import and export growth. In addition, an empirical framework also needs to take into account contemporaneous events and lagged effects in assessing the economic response to trade reforms; for instance, Greenaway et al. (2002) show in a dynamic model of growth that trade liberalization impacts the growth rates of real GDP per capita favorably, with the effect appearing to be modest, lagged and relatively persistent.

\footnotetext{
${ }^{1}$ Also see the useful discussions in Wei and Zhang (2010), Deaton (2010), and Rajan and Subramanian (2008).
} 
In this paper, we evaluate the impact of trade reforms on the growth of aggregate output, imports, and exports, explicitly taking into account a provision of trade adjustment assistance for trade reforms. To deal with the potential influence of a selection bias, our analysis first differentiates whether a country received trade adjustment assistance or not, and then studies its economic outcomes after trade reform. We proceed by reporting descriptive statistics of the initial conditions in both aid for trade recipient and non-recipient groups, followed by a formal specification to address the selection problem in the sample econometrically. Our study period is 1987-2004, when active lending by the World Bank coincided with major trade reforms, covering more than sixty countries and almost three hundred loans. Whether these trade adjustment loans were helpful to economic growth remains an open empirical question. Our findings suggest that these loans affected the recipient group more appreciably after trade reform, particularly concerning the growth of aggregate output and imports, while the effect on exports was rather mixed and relatively modest.

The rest of this paper is organized as follows. Section 2 reports background data and describes the initial conditions and economic outcomes in countries that underwent trade reforms during 19872004. Section 3 presents the empirical framework and discusses the econometric approach we use to deal with the selection bias and the endogeneity problem in a panel sample of aid recipient and nonrecipient countries. Section 4 reports the findings and Section 5 concludes.

\section{Background data}

Our sample focuses on the period of active trade adjustment lending by the World Bank spanning 1987-2004 and, subject to data availability, covers 45 developing countries that undertook major trade reforms. For each country, we study the data of two years before and eight years after trade reform. In total, we have a balanced panel of 450 country-year observations (with one observation for constructing a lag period). To determine this ten year window of country-year observations, we take into account several considerations. First, different countries carried out trade reforms at different periods in time, spanning the 1970s, 1980s, 1990s, and 2000s. Clearly, this implies that the empirical analysis is subject to both endogenous and selection bias since the implemented trade reform is likely dependent on various country-specific factors, prevailing aid conditionality, as well as global economic cycles. This inevitable challenge is also faced by most macroeconomic studies on trade adjustment assistance. Second, and consequentially, we have to set a comparable time frame to evaluate the effectiveness of trade adjustment lending across countries. It is not entirely clear how long before and after a trade reform would perfectly fit each country's economic circumstances. By looking at two years before and eight years after reform, the objective is to have a study window for comparison across countries. This is of course subject to data limitations, but it serves the objective of this study, which is to examine the effectiveness of trade adjustment loans on trade reforms. Third, we exclude countries that did not carry out major trade reforms, as their inclusion would entail conducting a differences-in-differences-in-differences investigation, which is beyond the goal of this study, and subject to the currently available empirical methodology that we find plausible given the set of countries under focus. That being said, there could still be a case that policy interventions, be they tax, trade, or monetary policy, may have little effect on the targeted outcome due to some unobserved common causes driving all the observable variation. In this vein, focusing on each country's specific window of two years before and eight years after trade reform may help mitigate an empirical challenge, whereby if non-reformers were included, it is uncertain what time frame or years of study should be applied to the non-reformer group of countries to examine the role of aid for trade reform.

To be selected for the sample, countries must have undertaken one or more identifiable trade reform programs in the study period. Given this criterion, Sub-Saharan Africa, Latin America, and Asia make up 38 percent, 33 percent, and 13 percent, respectively. Given a small number of countries for Europe and Central Asia (Turkey), Middle East (three countries) and South Asia (three countries), a regional breakdown of descriptive statistics is treated with caution. Countries that experienced a major civil conflict (following Collier et al., 2004) during the sample period were excluded, i.e. Afghanistan, Angola, Liberia, and Rwanda. Centrally planned economies in transition (e.g., part of the former Soviet Union during the study period) were also excluded. Out of these forty-five countries in 
the final sample, thirty-five countries received trade adjustment loans from the World Bank to aid the implementation of trade reforms.

We identify a year of major trade reform for each country and use this as a basis in our empirical analysis. Our identification of trade reform years across countries is due to the criteria examined in the Operations Evaluation Department (Jinjarak and Salinas, 2005), which are based on both the literature and the qualitative description provided in the sources referred to in this paper. Essentially, we study the evolution of average tariffs and non-tariff barriers, and classify a country's trade policy accordingly by its initial restrictiveness, final restrictiveness, and pace of reform, as explained below.

Initial Restrictiveness: based on average tariffs and non-tariff barriers. Countries in our sample are assigned to one of the following four categories: I.i) restrictive but degree unknown (not enough information to differentiate the degree of restrictiveness though clearly not open); I.ii) extremely restrictive (either non-tariff barriers frequency ratio above $60 \%$, simple average tariff above $80 \%$, standard deviation of tariffs above 30, or communist country); I.iii) highly restrictive (non-tariff barriers between $25 \%$ and $80 \%$ and tariffs between $30 \%$ and $80 \%$ ); I.iv) restrictive (either non-tariff barriers frequency ratio between $5 \%$ and $30 \%$ and average tariffs between $20 \%$ and $80 \%$, or non-tariff barriers between $30 \%$ and $80 \%$ and tariffs below 15\%); and I.v) open.

Final Restrictiveness: based on the following indices and indicators; IMF trade restrictiveness index, CPIA trade indicator, average unweighted tariff, frequency ratios of non-tariff barriers, black market premium, tariff escalation, existence of a major state monopoly in trade, use of export repatriation requirements, use of restrictions to current account transactions. The final restrictiveness is then classified into the following categories: F.i) highly open (at the end of the period, tariffs are at most moderate, non-tariff barrier regime is open; black market exchange rate premium is below $10 \%$; there is no state monopoly in trade; CPIA trade indicator was 4.5 or above in 1999-2001; else, countries with significant tariff escalation; export repatriation requirements; or restrictions to current account transactions are excluded from this category; F.ii) open (initially 'not open', but at the end of the period, tariffs are at most moderate, non-tariff barrier regime is open; no state monopoly in trade; CPIA trade indicator was 4.0 or above in 1999-2001); F.iii) moderately open (does not qualify as F.i) or F.ii); and F.iv) restrictive (either non-tariff barriers are restrictive or non-tariff barriers are moderate and tariffs are relatively restrictive; no significant reduction in tariffs and non-tariff barriers is recorded).

Pace of trade reform: P.i) rapid (most of the tariff and non-tariff reduction happened within a 3-year period); P.ii) gradual (trade reform happened slowly). As trade policy can be reformed at different paces, for countries that went through the reform gradually, a year of trade reform is identified as the time when a reduction in trade barriers started. In the case of countries that underwent trade reform rapidly, a year of reform is identified when a large reduction in trade barriers started, even though in some cases the rapid reform was preceded by minor trade liberalization. ${ }^{2}$ Appendix $\mathrm{B}$ contains the classification, presenting by country the initial conditions, pace of trade reform, and final restrictiveness of trade regimes.

Table 1 reports indicators of trade policy across countries in the sample. Trade regimes were extremely restrictive prior to the first wave of reforms that started in the early 1980s: average tariffs on goods were above 29 percent and non-tariff barriers frequency ratios were above 50 percent. Note that in addition to the high level of trade protection, countries frequently applied other restrictions to current account transactions and repatriation requirements related to exports profits. By region, the highest levels of protection were observed in South Asia and in the Middle East and North Africa. For the group of 35 countries that both implemented trade reforms and received trade adjustment loans from the World Bank, the initial levels of import tariff were lower at around 26 percent on average compared to 33 percent in the non-recipient group. However, the recipient group had a greater use of non-tariff barriers, registering 69 percent of tariff lines compared to 37 percent in the non-recipient countries prior to reform. As a result, for the recipient group the size of import duties as a percent of tax revenue tended to be lower than that observed in the non-recipient group in the sample.

\footnotetext{
${ }^{2}$ For example, this is the case in Argentina, where the identified year of trade reform is 1991, while a mild liberalization was already implemented in the late 1980s. If Argentina were classified as a gradual reformer, the selected year of reform would have been 1986, when the initial liberalization efforts started.
} 
Table 1

Indicators of trade policy.

\begin{tabular}{|c|c|c|c|c|c|c|c|c|c|c|c|c|c|c|c|c|}
\hline \multirow[t]{2}{*}{ Trade barriers } & \multirow[t]{2}{*}{$\begin{array}{l}\text { Period since } \\
\text { trade reform }\end{array}$} & \multirow[t]{2}{*}{ All } & \multicolumn{6}{|c|}{ Region } & \multicolumn{2}{|c|}{ Income level } & \multicolumn{2}{|c|}{$\begin{array}{l}\text { Recipient of } \\
\text { trade } \\
\text { adjustment } \\
\text { loans }\end{array}$} & \multicolumn{2}{|c|}{$\begin{array}{l}\text { Pace of trade } \\
\text { reform }\end{array}$} & \multicolumn{2}{|c|}{$\begin{array}{l}\text { Intensity of } \\
\text { trade reform }\end{array}$} \\
\hline & & & AFR & EAP & ECA & LAC & MNA & SAR & Low & Middle & Yes & No & Fast & Gradual & Intense & Not \\
\hline \multirow{4}{*}{ Average tariff (unweighted, \%) } & 0 & 30.4 & 24.4 & 30.8 & 22.7 & 28.1 & 26.0 & 69.7 & 34.5 & 28.7 & 31.9 & 27.6 & 34.3 & 27.6 & 30.7 & 30.6 \\
\hline & I & 27.9 & 24.7 & 23.1 & 9.5 & 23.9 & 40.6 & 68.9 & 29.2 & 27.1 & 29.1 & 21.0 & 28.8 & 27.1 & 21.7 & 29.4 \\
\hline & II & 20.8 & 20.8 & 23.7 & 9.5 & 13.5 & 25.0 & 48.0 & 24.7 & 18.2 & 23.1 & 14.7 & 18.9 & 23.2 & 21.7 & 20.7 \\
\hline & III & 17.6 & 18.1 & 21.4 & 8.3 & 12.0 & 26.8 & 31.6 & 21.1 & 15.1 & 18.5 & 15.4 & 17.6 & 18.0 & 16.8 & 18.2 \\
\hline \multirow[t]{4}{*}{ Non-tariff barriers (\% of tariff lines) } & 0 & 59.1 & 62.9 & 43.9 & 96.4 & 39.0 & 63.7 & 74.3 & 66.1 & 45.6 & 69.9 & 23.9 & 55.3 & 56.9 & 57.3 & 56.0 \\
\hline & I & 42.1 & 36.1 & 42.2 & 96.4 & 27.0 & 63.7 & 48.8 & 40.3 & 37.3 & 44.1 & 14.6 & 31.2 & 45.8 & 62.6 & 33.8 \\
\hline & II & 17.2 & 11.8 & 7.7 & 96.4 & 20.2 & 28.9 & 18.1 & 9.2 & 17.5 & 17.4 & 5.1 & 15.0 & 15.3 & 24.8 & 12.9 \\
\hline & III & 21.6 & 41.3 & 25.6 & 9.4 & 3.5 & 27.6 & 21.5 & 44.4 & 7.3 & 23.7 & 8.7 & 14.1 & 28.7 & 25.8 & 21.3 \\
\hline \multirow[t]{4}{*}{ Import duties (\% of tax revenue) } & 0 & 22.3 & 26.6 & 16.7 & 8.1 & 14.2 & 35.7 & 37.2 & 31.2 & 18.5 & 22.8 & 22.5 & 21.3 & 23.9 & 17.0 & 23.8 \\
\hline & I & 21.9 & 25.5 & 19.4 & 7.7 & 15.1 & 32.8 & 34.4 & 28.3 & 18.9 & 23.0 & 19.6 & 20.3 & 23.9 & 19.5 & 22.8 \\
\hline & II & 24.1 & 31.5 & 20.3 & 5.1 & 16.0 & 30.4 & 35.1 & 33.0 & 20.2 & 26.4 & 20.1 & 22.0 & 27.0 & 22.6 & 25.0 \\
\hline & III & 21.9 & 34.2 & 15.6 & 3.4 & 14.9 & 25.4 & 31.3 & 34.8 & 17.6 & 24.2 & 17.0 & 20.3 & 24.0 & 12.8 & 24.1 \\
\hline
\end{tabular}

Period since trade reform is defined as I for 1-2 years, II for 3-5 years, and III for 6-8 years. 
Table 2

Initial conditions: trade adjustment loan recipients and non-recipients.

\begin{tabular}{lcrc}
\hline Economic conditions & All & Recipients & Non-recipients \\
\hline Macroeconomic conditions & & & 96.0 \\
Real effective exchange rates & 96.4 & 96.4 & 20.4 \\
Inflation & 21.7 & 21.0 & -2.2 \\
Fiscal balance/GDP (\%) & -4.1 & -4.7 & 15.5 \\
Tax revenue/GDP (\%) & 13.8 & 13.4 & 24.3 \\
Investment to GDP (\%) & 19.7 & 18.3 & 1.8 \\
Per capita GDP growth (\%) & 0.8 & 0.4 & 6.5 \\
External conditions & & 5.3 & 0.6 \\
Exports growth (\%) & 6.1 & 2.4 & 64.5 \\
Imports growth (\%) & 2.3 & 52.6 & -2.1 \\
Trade to GDP (\%) & 54.7 & -4.4 & 102.7 \\
Current account balance to GDP (\%) & -3.8 & 98.2 & 41.1 \\
Terms of trade & 99.2 & 92.3 & 3.1 \\
Total external debt to GDP (\%) & 80.5 & 2.3 & \\
Reserves in months of imports (\%) & 2.5 & & \\
\hline
\end{tabular}

Across regions, trade reform was evident in our sample, with the exception of Africa, the Middle East and North Africa. While trade protection in Tunisia was high, its trade policy with large trading partners, i.e. the European Union, was going through significant liberalization under the trade agreement signed in 1995. Further, some countries in South Asia remained protected after reforms during the study period. Overall, the pattern of trade reforms was heterogeneous across regions, varying in pace and magnitude. Almost half of all reform episodes were implemented rapidly, with most of the reforms completed in less than three years. There was no geographical pattern to the speed of reform, though regions in South Asia, the Middle East and North Africa were more likely to be gradual reformers. Some countries in the sample implemented a dual scheme approach to trade reform, maintaining high protection of domestic industries, but providing liberal trade policies in the so-called export platforms, or export processing zones. About ten percent of the countries in the sample, mainly in East Asia (China, Vietnam), the Middle East and North Africa (Tunisia), followed this dual system approach.

Looking at Table 1, it appears as if trade adjustment loans from the World Bank did not significantly affect the intensity or speed of trade reforms. Non-recipient countries cut average tariffs by half, similar to the recipient group, and significantly reduced the frequency ratios of non-tariff barriers (as well as lowering restrictions on current account transactions and export repatriation requirements). While countries that underwent trade reforms with trade adjustment loans reduced non-tariff barrier frequency ratios more, this difference to the non-recipient group is not statistically significant. In addition, the non-recipient countries were as likely to implement trade reforms rapidly as was the recipient group.

Table 2 provides the initial economic conditions, contrasting the macroeconomic details of the recipient and non-recipient groups. On average, countries that received trade adjustment loans from the Work Bank tended to have more imbalances in the initial macroeconomic conditions, including significantly higher inflation and smaller tax bases, in comparison to other countries that undertook trade reforms on their own. The recipient group also faced greater external pressures, terms of trade fluctuations, lower growth, lower investment, and higher external debt-to-GDP ratios. These macroeconomic imbalances in the recipient group were often associated with balance of payments difficulties, presaging the tendency to seek trade adjustment assistance and external intervention. Table 3 reports macroeconomic conditions classified by region and income levels. High and persistent inflation was clearly evident in Latin America, while external imbalances were most pronounced in Africa, where current account deficits, terms of trade deterioration, and external debt difficulties were pervasive. Economic growth was modest for all countries in the sample, except East Asian economies. With average investment rates below 20 percent, meager FDI inflows and an anemic trade performance, overall GDP growth averaged below 3 percent, even though the fast-growing East Asian economies were included in the sample. In all regions except East and South Asia the low growth rate barely kept up with the level of population growth. 
Table 3

Initial conditions by region and income level.

\begin{tabular}{|c|c|c|c|c|c|c|c|c|c|}
\hline & \multirow[t]{2}{*}{ All } & \multicolumn{6}{|c|}{ Region } & \multicolumn{2}{|c|}{ Income level } \\
\hline & & AFR & EAP & ECA & LAC & MNA & SAR & Mid. & Low \\
\hline \multicolumn{10}{|l|}{ Macroeconomic conditions } \\
\hline Real effective exchange rates & 96.4 & 94.5 & 96.9 & 99.3 & 98.9 & 96.8 & 94.5 & 97.4 & 95.0 \\
\hline CPI Inflation & 21.7 & 20.2 & 7.2 & 73.7 & 34.3 & 7.3 & 6.9 & 22.7 & 18.6 \\
\hline Fiscal balance/GDP (\%) & -4.1 & -5.0 & -2.7 & -3.0 & -1.8 & -8.6 & -7.9 & -3.3 & -5.2 \\
\hline Tax revenue/GDP (\%) & 13.8 & 12.6 & 15.1 & 11.0 & 14.6 & 19.2 & 10.1 & 15.9 & 11.5 \\
\hline Investment to GDP (\%) & 19.7 & 15.9 & 27.2 & 25.1 & 19.7 & 23.6 & 20.8 & 22.0 & 16.7 \\
\hline Per capita GDP growth (\%) & 0.8 & -0.8 & 4.7 & 0.4 & 0.5 & -0.6 & 3.4 & 1.3 & -0.1 \\
\hline \multicolumn{10}{|l|}{ External conditions } \\
\hline Exports growth (\%) & 6.1 & 0.1 & 7.8 & 24.4 & 8.9 & 14.3 & 8.7 & 8.8 & 1.6 \\
\hline Imports growth (\%) & 2.3 & -2.2 & 6.9 & 3.0 & 3.6 & 8.5 & 2.5 & 4.0 & -0.4 \\
\hline Trade to GDP $(\%)$ & 54.7 & 53.1 & 51.7 & 36.2 & 60.8 & 76.8 & 27.2 & 61.2 & 47.8 \\
\hline Current account/GDP (\%) & -3.8 & -4.7 & -2.9 & 1.8 & -3.1 & -4.7 & -4.3 & -2.9 & -5.0 \\
\hline Terms of trade & 99.2 & 97.8 & 97.6 & 101.5 & 102.5 & 100.0 & 94.7 & 100.9 & 97.0 \\
\hline Total external debt to GDP (\%) & 80.5 & 89.7 & 76.0 & 45.5 & 83.8 & 77.7 & 37.9 & 71.4 & 93.4 \\
\hline Reserves (months of imports) & 2.5 & 1.8 & 3.1 & 2.5 & 3.2 & 1.8 & 3.2 & 2.9 & 2.1 \\
\hline
\end{tabular}

Evidently, Tables 1-3 suggest several causes that were unfavorable and common to all countries prior to their major trade reforms. However, between the recipients of trade adjustment loans and the non-recipient group, there are marked differences that could potentially influence the economic performance after trade reforms. We attempt to account for these differences more formally in the following section.

\section{Empirical specification}

In order to assess the economic impact of trade reform and the effectiveness of trade adjustment assistance for trade simultaneously, we need to formally take into account a selection bias potentially driven by the provision of trade adjustment loans. The underlying model of the outcome variable $\left(y_{i t}\right)$ is specified as:

$$
y_{i t}=a x_{i t}+b s_{i t}+f w_{i t}+c_{i l}+u_{i t}, \quad t=1, \ldots, T,
$$

where $x_{i t}$ is a set of policy variables that would have been observable in the absence of trade adjustment lending in country $i$ at time $t$; $s_{i t}$ is a dummy variable for country $i$ in year $t$ for being in the recipient group; $w_{i t}$ is a vector of explanatory variables; $c_{i l}$ represents unobservable country-specific effects, and $u_{i t}$ is the error term. We conduct the estimation in two stages, with the first stage estimating the probability of participation, $s_{i t}$, and the second stage estimating the effect of trade reforms in the presence of trade adjustment loans.

In this specification, we attempt to take into account several considerations that are specific to the present empirical question. First, trade adjustment assistance and its conditionality are typically tied to policy variables, i.e. the level and dispersion of import tariffs, and the existence and scope of nontariff barriers. However, the success of trade adjustment assistance is measured by aggregate economic outcomes, which are potentially influenced by a wide range of other policy variables (e.g., monetary, fiscal and exchange rate policies, financial sector and labor market reforms, as well as supply-side policies affecting the productivity of domestic firms). This makes it difficult to conclude that trade reforms and aid for trade lead to expanded trade and economic growth. Based on the literature on evaluation frameworks for trade adjustment assistance, our specification is an attempt to address not only the economic growth outcome, but also other important considerations including the selection bias, endogeneity, and policy reaction. Given the research question and data availability over the specific episode we are interested in, we cannot accommodate a large set of specifications and variables in an exhaustive and experimental way, e.g. that of Sala-I-Martin (1997). Second, even when all relevant policy variables take optimal values, exogenous shocks and external factors can still affect 
the aggregate outcomes. These shocks may include terms of trade movements and natural disasters (i.e. droughts and hurricanes). Third, the empirical specification also has to deal with the counterfactual, specifically what would have happened to the country's trade policies and economic outcomes in the absence of trade adjustment assistance. Since the counterfactual is not observable, an approximation is necessary. A number of studies have attempted to construct relevant counterfactuals to isolate the impact of trade adjustment assistance, notably Conway $(1994,1998)$ and Atoyan and Conway (2006).

To describe our two stage approach in detail, we refer to a procedure proposed by Heckman (1979). In the first stage, the probability of participation in trade adjustment lending is estimated as a function of growth, inflation, external debt, terms of trade, and natural disasters. In the second stage, the inverse Mill's ratio from the first stage is included in the growth estimation to account for the potential selection bias from the provision of trade adjustment loans. Specifically, in the first stage, the probability of a country receiving any trade adjustment lending from the World Bank is obtained from the Probit estimation:

$$
\begin{array}{ll}
s_{i t}^{*}=g x_{i t 2}+c_{i 2}+v_{i t} \\
s_{i t}=1 \quad \text { if } s_{i t}^{*}>0 \\
0 \quad \text { if } s_{i t}^{*} \leq 0
\end{array}
$$

We observe $y_{i t}$ when a country $i$ receives a trade adjustment loan in year $t$, and hence $s_{i t}=1$ for the recipient group. As discussed in Wooldridge (2010), under any assumption that allows for an unobserved effect in the selection equation, adding the inverse Mill's ratio obtained from the Probit results and then using fixed effects in a follow-up estimation does not produce consistent estimators. This is because of another potential problem - the presence of unobserved heterogeneity arising from different country characteristics. In a linear panel data analysis, the unobserved heterogeneity is differenced out using fixed effects models. In the present context, consistent estimates are obtained by first estimating a Probit of $s_{i t}$ on $x_{i}$ for each $t$, saving the inverse Mill's ratio, denoted by $\lambda_{i t}$, for all $i$ and $t$, and then running the pooled OLS regression using:

$$
y_{i t} \text { on } x_{i t}, \bar{x}_{i}, \lambda_{i t} \text { for all } s_{i t}=1
$$

Next, to allow for unobservable country-specific effects and non-random sample selection in the panel data, following Wooldridge (2010),

$$
s_{i t}=1\left[g_{t} x_{i}+c_{i 2}+v_{i t}>0\right], v_{i t} \mid\left(x_{i}, c_{i 1}, c_{i 2}\right) \sim \operatorname{Normal}(0,1),
$$

which is a reduced-form selection equation that lets the explanatory variables in all time periods appear in the selection equation at time $t$. Following Mundlak (1978), we replace $x_{i}$ with $\left(x_{i t}, \bar{x}_{i}\right)$ at time $t$, thereby allowing coefficients to be constant across time and conserving the degrees of freedom.

In the second stage, we estimate the effect of trade adjustment assistance and trade reform on economic outcomes. To construct a counterfactual for what policies $x_{i t}$ a country would have implemented in the absence of a trade adjustment loan, a policy reaction function is estimated to relate changes in the policy variables with the deviation of the observed lagged value of each outcome variable from its desired value:

$$
\Delta x_{i t}=d_{i}\left[y_{i t}^{d}-y_{i t-1}\right]+e_{i t},
$$

where $y_{i t}^{d}$ is the desired outcome value of $y_{i t}$, assumed to be invariant across countries and over time for the study period; $d_{i}$ measures adjustment to disequilibrium in the target value; and $e_{i t}$ is the unobservable error term. For a detailed discussion and motivation on this type of policy reaction function, see Goldstein and Montiel (1986), Khan and Montiel (1989), Faini et al. (1991), and Conway (1994). Substituting the participation function (4) and policy reaction function (5) into Eq. (1), we obtain:

$$
\Delta y_{i t}=-(a d+1) y_{i t-1}+a x_{i t-1}+b s_{i t}+f w_{i t}+c_{i 1}+\left(u_{i t}+a e_{i t}\right), \quad t=1, \ldots, T
$$

\footnotetext{
${ }^{3}$ The inverse Mill's ratio, introduced by Heckman (1979), is a monotonically decreasing function (ranging from 0 to infinity) of the probability that an observation is selected into the sample of non-program or non-participating countries.
} 
Table 4

Growth of real GDP per capita after trade reform.

\begin{tabular}{|c|c|c|c|}
\hline \multirow{2}{*}{$\begin{array}{l}\text { Dependent variable: growth rates of } \\
\text { real GDP per capita }\end{array}$} & \multirow[t]{2}{*}{ Baseline estimation } & \multicolumn{2}{|c|}{ Correction for panel sample selection } \\
\hline & & Bank assistance & No bank assistance \\
\hline Lagged growth rate of real GDP per capita & $\begin{array}{l}-0.68 \\
(7.90)^{* * *}\end{array}$ & $\begin{array}{l}-1.05 \\
(12.38)^{* * *}\end{array}$ & $\begin{array}{l}-0.98 \\
(18.49)^{* * *}\end{array}$ \\
\hline $0-2$ yrs since trade reform & $\begin{array}{l}1.10 \\
(1.57)\end{array}$ & $\begin{array}{l}1.08 \\
(1.33)\end{array}$ & $\begin{array}{l}1.06 \\
(0.64)\end{array}$ \\
\hline $3-5$ yrs since trade reform & $\begin{array}{l}1.24 \\
(2.01)^{*}\end{array}$ & $\begin{array}{l}1.91 \\
(2.60)^{* *}\end{array}$ & $\begin{array}{l}1.72 \\
(2.38)^{* *}\end{array}$ \\
\hline $6-8$ yrs since trade reform & $\begin{array}{c}0.83 \\
(1.08)\end{array}$ & $\begin{array}{l}2.40 \\
(2.62)^{* *}\end{array}$ & $\begin{array}{c}0.46 \\
(0.50)\end{array}$ \\
\hline Inflation reduction & $\begin{array}{l}-0.64 \\
(1.25)\end{array}$ & $\begin{array}{c}1.08 \\
(1.58)\end{array}$ & $\begin{array}{l}-0.76 \\
(0.77)\end{array}$ \\
\hline $\begin{array}{l}\text { Dummy variable for presence of } \\
\text { trade adjustment loans }\end{array}$ & $\begin{array}{l}-0.50 \\
(0.62)\end{array}$ & & \\
\hline $\begin{array}{l}\text { Inverse Mill's ratio to control for selection } \\
\text { of trade assistance and unobserved } \\
\text { heterogeneity }\end{array}$ & & $\begin{array}{l}-0.36 \\
(0.86)\end{array}$ & $\begin{array}{c}0.96 \\
(1.90)^{*}\end{array}$ \\
\hline Observations & 450 & 350 & 100 \\
\hline Adjusted $R$-squared & 0.34 & 0.53 & 0.48 \\
\hline Test for homoscedasticity ( $p$-value) & 0.11 & 0.09 & 0.06 \\
\hline Test for normality of residuals ( $p$-value) & 0.00 & 0.00 & 0.00 \\
\hline
\end{tabular}

Standard errors are in parentheses, with ${ }^{* * *}\left({ }^{* *},{ }^{*}\right)$ denoting $1(5,10)$ significant level.

Note that we need to enforce the equality of parameter $a$ across groups, otherwise Eq. (5) will not adjust for differences in these variables across groups. This approach helps mitigate the simultaneous presence of sample selectivity $\left(s_{i t}\right)$ and unobserved heterogeneity $\left(c_{i 1}, c_{i 2}\right)$ that we aim to control for in our estimation.

\section{Estimation results}

In Tables 4-6, we present our estimation results for three outcome variables $\left(y_{i t}\right)$ : growth of real GDP per capita, growth of import demand, and growth of export supply. Following the above empirical specification, the control for unobservable country-specific effects is accounted for by the inverse Mills ratio, obtained in the first stage from estimating for each time period the Probit of a dummy variable for trade adjustment loan on lagged real GDP per capita growth, lagged dummy for inflation of 40 percent or higher, lagged external debt to GDP ratio, and a lagged natural disaster dummy. The estimated inverse Mill's ratios are then entered into the second stage regression, whereby any statistical insignificance of the inverse Mill's ratio indicates that the potential sample selection bias has been dealt with in the present context. ${ }^{4}$

Table 4 reports the results when the outcome variable is the growth rate of real GDP per capita. The variable of interest is the number of years since trade reform started, defining a dummy variable (LIB) for each period: let $t=0$ be the year of trade reform identified earlier, then $\operatorname{LIB}[0,2]=1$ for $t$ to $t+2$, and 0 otherwise; $\operatorname{LIB}[3,5]=1$ for $t+3$ to $t+5$; and 0 otherwise, $\operatorname{LIB}[6,8]=1$ for $t+6$ to $t+8$, and 0 otherwise. The estimated coefficients of trade reform variables indicate the effects of trade reform on economic growth in the short run (between 0 and 2 years), medium run (between 3 and 5 years), and long run (between 6 and 8 years), relative to the two year period ( $t-2$ to $t-1)$ preceding the reform years. Wacziarg and Welch (2008) use a similar specification of dummy variables to account for the effects of trade reform. Using this type of reform variables mitigates the endogeneity bias that may arise from the correlation between tariffs and other economic factors, e.g. inflation, real output, and

\footnotetext{
${ }^{4}$ Note that the panel data spans periods of ten years for all countries, but these are different 10 years for different countries. An alternative specification may try to control for common trends in the growth of global trade as an explanatory variable in the estimates, also accounting for the pattern of trade growth for the non-reforming developing countries. In addition, it may also be useful to estimate the model using the trade intensity ratio as the dependent variable.
} 
Table 5

Growth of imports after trade reform.

\begin{tabular}{lccc}
\hline Dependent variable: growth rates of imports & Baseline estimation & \multicolumn{2}{c}{ Correction for panel sample selection } \\
\cline { 2 - 4 } & & Bank assistance & No bank assistance \\
\hline Lagged growth rate of imports & -0.95 & -1.00 & -1.15 \\
& $(20.71)^{* * *}$ & $(15.39)^{* * *}$ & $(22.16)^{* * *}$ \\
0-2 yrs since trade reform & 9.45 & 8.26 & 11.43 \\
& $(2.79)^{* * *}$ & $(1.90)^{*}$ & $(2.94)^{* *}$ \\
3-5 yrs since trade reform & 14.85 & 14.37 & 10.77 \\
& $(2.79)^{* * *}$ & $(2.25)^{* *}$ & $(1.15)$ \\
6-8 yrs since trade reform & 22.37 & 23.93 & 8.56 \\
& $(2.79)^{* * *}$ & $(2.54)^{* *}$ & $(0.66)$ \\
REER changes & 0.40 & 0.31 & 0.53 \\
& $(4.44)^{* * *}$ & $(2.79)^{* * *}$ & $(3.64)^{* * *}$ \\
Lagged capita GDP growth rates & 1.05 & 1.19 & 1.32 \\
& $(5.37)^{* * *}$ & $(4.20)^{* * *}$ & $(2.69)^{* *}$ \\
Time trend & -2.54 & -2.92 & 0.12 \\
& $(2.68)^{* *}$ & $(2.68)^{* *}$ & $(0.08)$ \\
Dummy variable for presence of trade & 2.18 & & -0.33 \\
adjustment loans & $(1.32)$ & -0.17 & $(0.10)$ \\
Inverse Mill's ratio to control for selection & & $(0.11)$ & 100 \\
of trade assistance and unobserved heterogeneity & & 350 & 0.60 \\
Observations & 450 & 0.52 & 0.78 \\
Adjusted $R$-squared & 0.51 & 0.00 & 0.00 \\
Test for homoscedasticity ( $p$-value) & 0.02 & 0.00 & \\
Test for normality of residuals $(p$-value) & 0.00 & & \\
\hline
\end{tabular}

Standard errors are in parentheses, with ${ }^{* * *}\left(* *,{ }^{*}\right)$ denoting $1(5,10)$ significant level.

Table 6

Growth of exports after trade reform.

\begin{tabular}{|c|c|c|c|}
\hline \multirow{2}{*}{$\begin{array}{l}\text { Dependent variable: changes in growth } \\
\text { rates of exports }\end{array}$} & \multirow[t]{2}{*}{ Baseline estimation } & \multicolumn{2}{|c|}{ Correction for panel sample selection } \\
\hline & & Bank assistance & No bank assistance \\
\hline Lagged growth rate of exports & $\begin{array}{l}-0.83 \\
(13.79)^{* * *}\end{array}$ & $\begin{array}{l}-0.96 \\
(19.41)^{* * *}\end{array}$ & $\begin{array}{l}-1.05 \\
(7.37)^{* * *}\end{array}$ \\
\hline $3-5$ yrs since trade reform & $\begin{array}{c}1.71 \\
(1.24)\end{array}$ & $\begin{array}{l}2.59 \\
(1.70)^{*}\end{array}$ & $\begin{array}{c}0.38 \\
(0.15)\end{array}$ \\
\hline $6-8$ yrs since trade reform & $\begin{array}{c}1.34 \\
(1.01)\end{array}$ & $\begin{array}{l}2.59 \\
(1.97)^{*}\end{array}$ & $\begin{array}{l}-0.55 \\
(0.22)\end{array}$ \\
\hline REER changes & $\begin{array}{l}-0.13 \\
(2.04)^{* *}\end{array}$ & $\begin{array}{l}-0.16 \\
(1.59)\end{array}$ & $\begin{array}{l}-0.08 \\
(1.86)\end{array}$ \\
\hline Lagged REER changes & $\begin{array}{l}-0.08 \\
(1.40)\end{array}$ & $\begin{array}{l}-0.12 \\
(1.90)^{*}\end{array}$ & $\begin{array}{c}-0.15 \\
(1.20)\end{array}$ \\
\hline Infrastructure & $\begin{array}{l}1.70 \\
(0.70)\end{array}$ & $\begin{array}{l}4.17 \\
(3.82)^{* * *}\end{array}$ & $\begin{array}{r}-11.16 \\
(0.15)\end{array}$ \\
\hline $\begin{array}{l}\text { Dummy variable for presence of trade } \\
\text { adjustment loans }\end{array}$ & $\begin{array}{c}0.23 \\
(0.17)\end{array}$ & & \\
\hline $\begin{array}{l}\text { Inverse Mill's ratio to control for selection } \\
\text { of trade assistance and unobserved heterogeneity }\end{array}$ & & $\begin{array}{l}-1.70 \\
(1.46)\end{array}$ & $\begin{array}{c}0.30 \\
(0.29)\end{array}$ \\
\hline Observations & 346 & 270 & 76 \\
\hline Adjusted $R$-squared & 0.44 & 0.48 & 0.50 \\
\hline Test for homoscedasticity ( $p$-value) & 0.72 & 0.65 & 0.29 \\
\hline Test for normality of residuals ( $p$-value) & 0.00 & 0.01 & 0.01 \\
\hline
\end{tabular}

Standard errors are in parentheses, with ${ }^{* *}\left({ }^{* *},{ }^{*}\right)$ denoting $1(5,10)$ significant level. 
unemployment, or changes in the composition of imports. In addition, this specification also reduces the missing observation problem prevalent in the case of using tariff measures.

Note that we use annual data in the estimation to study the aid for trade episode of interest when trade adjustment lending by the World Bank was quite active. While a five or ten year average is typically employed in some studies to account for any business cycle effect in the data, it is not clear to us what would be a country-specific start and end year if we want to purge out the business cycles effectively, short of information similar to the NBER business cycles. Collapsing the annual information into an arbitrary period average also poses some challenge to us as it is the annual variation in economic performance that we wish to track after each country's trade reform. By using annual data, we are able to look at the short and medium run effect of the trade adjustment loans more effectively compared to other configurations.

For comparison, the left most column of Table 4 first presents the results when the sample selection bias is not dealt with; in this simple specification, trade reform has a positive impact on per capita GDP growth in the medium and long run, but this positive effect is quite small and statistically insignificant for the recipient group. The next two columns report a pooled OLS estimation that controls for unobserved country-specific factors and a sample selection bias due to Eq. (6). The differences in the coefficient estimates between the recipient and non-recipient groups suggest that the effects of trade reforms are dependent of the provision of trade adjustment loans. Thus, unlike in column one, the estimation results in columns two and three have the advantage of allowing for a full set of interactions between trade adjustment assistance and trade reforms, among other explanatory variables.

Based on our preferred specification, the overall explanatory power of the estimation is reasonably good with the adjusted $R^{2}$ of $0.48-0.53$. Note that the positive effect of trade reform on per capita GDP growth in the short run is statistically indistinguishable from zero; this absence of short-term gains in aggregate output may be driven by other concurrent stabilization programs in the country. It is also possible that a large-scale macroeconomic adjustment and stabilization could initially be associated with a contraction in output in the short run. Nevertheless, our results suggest that trade adjustment loans increased GDP growth for the recipient group by about 2 percent in the medium term after trade reform; this is 0.2 percent above the non-recipient group. In the long term, trade adjustment lending increased growth by $2.4 \%$, whereas the non-recipient group did not register any long-run effects after trade reform. To compare our results with the literature, Wacziarg and Welch (2008) find that the effects of trade reforms on per capita GDP in the short, medium and long run are - 0.5-0.5 percent, 0.8-2.0 percent, and 1.0-1.5 percent, respectively, which is generally lower than the estimates in our preferred specification.

Next in line are the estimation results with import growth as a dependent variable, reported in Table 5. Compared to the pre-reform period, the short-run positive effect of trade reform on the growth of import demand is 8 percent for the recipient group and 11 percent for the non-recipient group. The findings are consistent with Santos-Paulino and Thirlwall (2004), who found that import growth increased by about 6 percent following trade reform. Appreciation of the real effective exchange rate and lagged GDP growth had the expected positive effects on the growth of imports. The real exchange rates appeared to be an important determinant of import demand, with stronger effects on import demand growth for the non-recipient group in the short run. For the recipient group, import growth increased significantly in all periods after trade reform, while for the non-recipient group import growth did not register any statistically significant increase in the medium and long term. By including an exogenous time trend, we hope to assess whether import growth follows any particular pattern after trade reform, and find that there is some trending toward lower import growth for the recipient group. Compared to the non-recipient group, the presence of trade adjustment loans increased import growth by an additional 6 percent in the medium term and 10 percent in the long term.

In Table 6, we report the results for export growth. As expected, coefficient estimates on the real effective exchange rates are negative for both recipient and non-recipient groups. The regression for the recipient group shows that trade reforms have a positive and statistically significant impact on export growth, whereas the impact of trade reform on the export growth rate is statistically indistinguishable from zero for the non-recipient group. Nonetheless, the effects of trade reform 
on export supply response are modest on average. The presence of trade adjustment loans is associated with a 2.5 percent higher growth of exports during the three to eight years after trade reform. One interpretation of this low export supply response may be due to greater regulatory barriers and infrastructure constraints that hinder the export supply response existing prior to trade reforms in the recipient group. To control for this possibility, a measure of the level of infrastructure is included in the regression, where it is measured as the length (in kilometers) of the total road and railroad network per square kilometer of land area. We find that the coefficient estimate on the infrastructure variable is positive and statistically significant for the recipient group, but not for the non-recipient countries. The fact that the infrastructure is especially important to the recipient group in our analysis may also justify the provision of trade adjustment lending in the first place. ${ }^{5}$

\section{Conclusions}

This paper applies a panel regression to examine the effect of trade adjustment assistance on the economic outcome after trade reform. Our study focuses on trade adjustment lending extended by the World Bank to countries that underwent major trade reforms during the period from 1987 to 2004. We take into account a potential sample selection bias that may arise in the presence of trade adjustment loans as well as the endogeneity problem in a cross-country time-series panel that may be driven by unobservable country-specific effects. The empirical results suggest that for the capita GDP growth, trade adjustment loans yielded significant and beneficial impacts on the recipient countries, with additional gains emerging between three to eight years after trade reform. For both recipient and non-recipient countries, trade reforms increased import growth, with subsequent gains that sustained over a longer period for the recipient group. The favorable impact of trade reforms and trade adjustment loans on export growth were rather modest relative to the impact on GDP growth and import growth.

Our findings also point to the importance of the selection bias and endogeneity in the panel data when trade adjustment assistance is studied: for instance, a simple linear regression underestimated the impact of trade reform on per capita GDP growth by about 2.5 percent in the long run. We also note that a small export supply response found in the recipient group may imply that, despite the overall gain in economic growth due to trade reform, the level of a country's infrastructure remains crucial to the success of trade adjustment assistance and policy intervention. The fact that infrastructure is especially important to the recipient group in our analysis may also justify the provision of trade adjustment lending in the first place. Obviously, the historical account presented in this study is open to many other interpretations. An important consideration, though difficult to account for empirically, is the credibility of trade reform itself (Rodrik, 2007). Further useful research in this area should also address a greater delineation of trade reform and aid for trade, incorporate political and institutional factors, as well as provide additional case studies that examine more deeply country-specific policy measures, both tariff and non-tariff barriers, on external trade of the developing countries. ${ }^{6}$

\section{Acknowledgements}

We would like to thank two reviewers for useful comments, as well as Patrick Conway, Jaime de Melo, Amornrat Kritsophon, Piyachart Phiromswad, Guobing Shen, seminar participants at the CCESSSEM at Fudan University, Sasin Graduate Institute of Business Administration of Chulalongkorn University, and the Operations Evaluation Department at the World Bank.

\footnotetext{
${ }^{5}$ Note that the liberalization increased import growth more than export growth, yet overall economic growth increased. Higher imports directed at intermediaries, machineries, and capital goods can increase the overall productive capacity, satisfying both higher domestic demand and foreign exports, and hence increasing economic growth.

${ }^{6}$ Subject to the availability of longer time series, alternative specifications may try to account for cyclical effects (growth of domestic income for imports; growth world income for exports), together with measures of capital and human capital. Further, a larger comprehensive set of countries that went through several reforms may be useful to study whether trade liberalization was coincident with other reforms that may have increased growth.
} 


\section{Appendix A. Data sources}

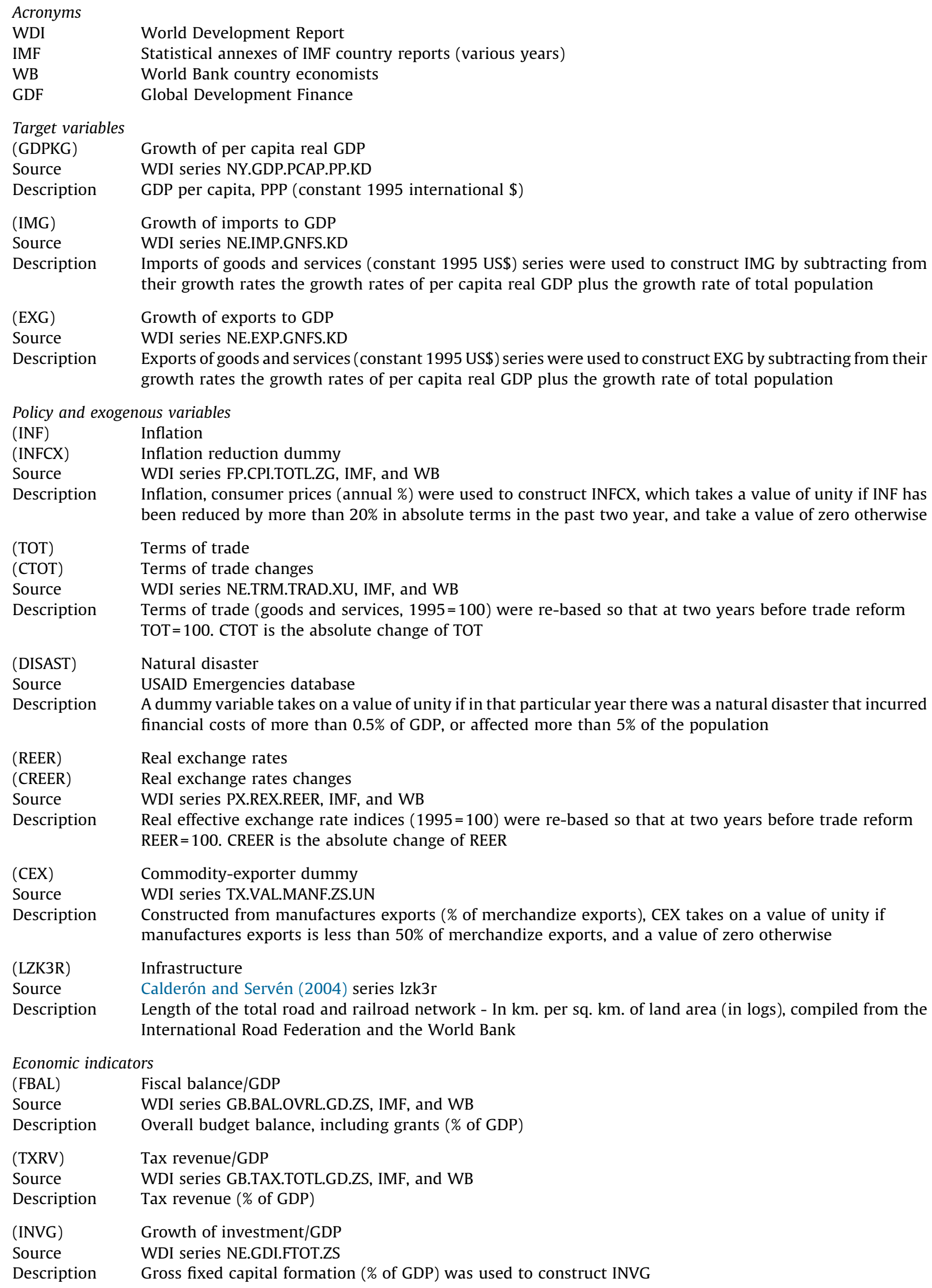


Appendix A (Continued)

(OPEN)

Source

Description

(CABL)

Source

Description

(DEBT)

Source

Description

(FXRS)

Source

Description

(DEMOC)

Source

Description

(REG2004)

Source

Description

(RULE2002)

Source

Description
Trade/GDP

WDI series NE.TRD.GNFS.ZS

Measure of openness, calculated as the sum of exports and imports of goods and services measured as a percentage of gross domestic product

Current accounts balance/GDP

WDI series BN.CAB.XOKA.GD.ZS

The sum of net exports of goods, services, net income, and net current transfers as a percentage of GDP

Total external debt/GNI

WDI series DT.DOD.DECT.GN.ZS, IMF, and WB

Total external debt to gross national income

Reserves in months of imports

GDF series FI.RES.TOTL.MO

Net international reserves in months of imports

Institutionalized democracy

Polity IV Project (Political Regime Characteristics and Transitions, 1800-2002) http://www.cidcm.umd.edu/ inscr/polity/

(numeric) Range $=0-10$ ( $0=$ low; 10 =high) Democracy Score: general openness of political institutions

Index of regulations

The World Bank-Doing Business in 2004, http://rru.worldbank.org/DoingBusiness/

Following Bolaky and Freund (2004), the 2004 index of regulations is an average of the index of labor regulations and the index of entry regulations. The final values of the regulation index ranging from 3.74 to 4.08 for all 144 countries in the database, and from 3.81 to 4.08 for 42 countries of our 45 countries sample available from the database

Rule of law

Kaufmann et al. (2004), http://www.worldbank.org/wbi/governance/pubs/govmatters3.html

The rule of law index represents "the extent to which agents have confidence in and abide by the rules of society. These include perceptions of the incidence of both violent and non-violent crime, the effectiveness and predictability of the judiciary, and the enforceability of contracts." (Kaufmann et al., 2004, page 4)

\section{Appendix B. Classification of trade reforms}

\begin{tabular}{|c|c|c|c|c|c|c|c|c|c|}
\hline \multirow{2}{*}{$\begin{array}{l}\text { Region } \\
\text { AFRICA }\end{array}$} & \multirow[b]{2}{*}{ Cameroon } & \multicolumn{2}{|c|}{ Income level } & \multicolumn{2}{|c|}{ Population level } & \multicolumn{2}{|c|}{$\begin{array}{l}\text { Trade adjustment } \\
\text { loans }\end{array}$} & \multicolumn{2}{|c|}{ Pace of trade reform } \\
\hline & & LOW & Cameroon & SMALL & Cameroon & NO & Brazil & GRADUAL & Brazil \\
\hline & Central & & Central & & Central & & Central & & China \\
\hline & AFR Rep. & & AFR Rep. & & AFR Rep. & & AFR Rep. & & \\
\hline & Cote d'Ivoire & & Cote d'Ivoire & & Chile & & China & & Costa Rica \\
\hline & Ghana & & Ghana & & Costa Rica & & Ecuador & & Cote d'Ivoire \\
\hline & Kenya & & India & & Cote d'Ivoire & & Korea, & & Dominican \\
\hline & & & & & & & Rep. of & & Rep. \\
\hline & Lesotho & & Kenya & & $\begin{array}{l}\text { Dominican } \\
\text { Rep. }\end{array}$ & & Lesotho & & India \\
\hline & Madagascar & & Lesotho & & Ecuador & & Paraguay & & Indonesia \\
\hline & Malawi & & Madagascar & & Ghana & & South Africa & & Jamaica \\
\hline & Mali & & Malawi & & Honduras & & Trinidad & & Jordan \\
\hline & & & & & & & \&Tobago & & \\
\hline & Mauritius & & Mali & & Jamaica & & Venezuela & & Kenya \\
\hline & Niger & & Nepal & & Jordan & YES & Argentina & & Madagascar \\
\hline & Nigeria & & Niger & & Lesotho & & Cameroon & & Malawi \\
\hline & Senegal & & Nigeria & & Madagascar & & Chile & & Mauritius \\
\hline & South Africa & & Pakistan & & Malawi & & Colombia & & Morocco \\
\hline & Tanzania & & Senegal & & Mali & & Costa Rica & & Nepal \\
\hline & Zambia & & Tanzania & & Mauritius & & Cote d'Ivoire & & Niger \\
\hline & Zimbabwe & & Vietnam & & Nepal & & Dominican & & Nigeria \\
\hline & & & & & & & Rep. & & \\
\hline EAP & China & & Zambia & & Niger & & Ghana & & Panama \\
\hline & Indonesia & & Zimbabwe & & Panama & & Honduras & & Paraguay \\
\hline
\end{tabular}


Appendix B (Continued)

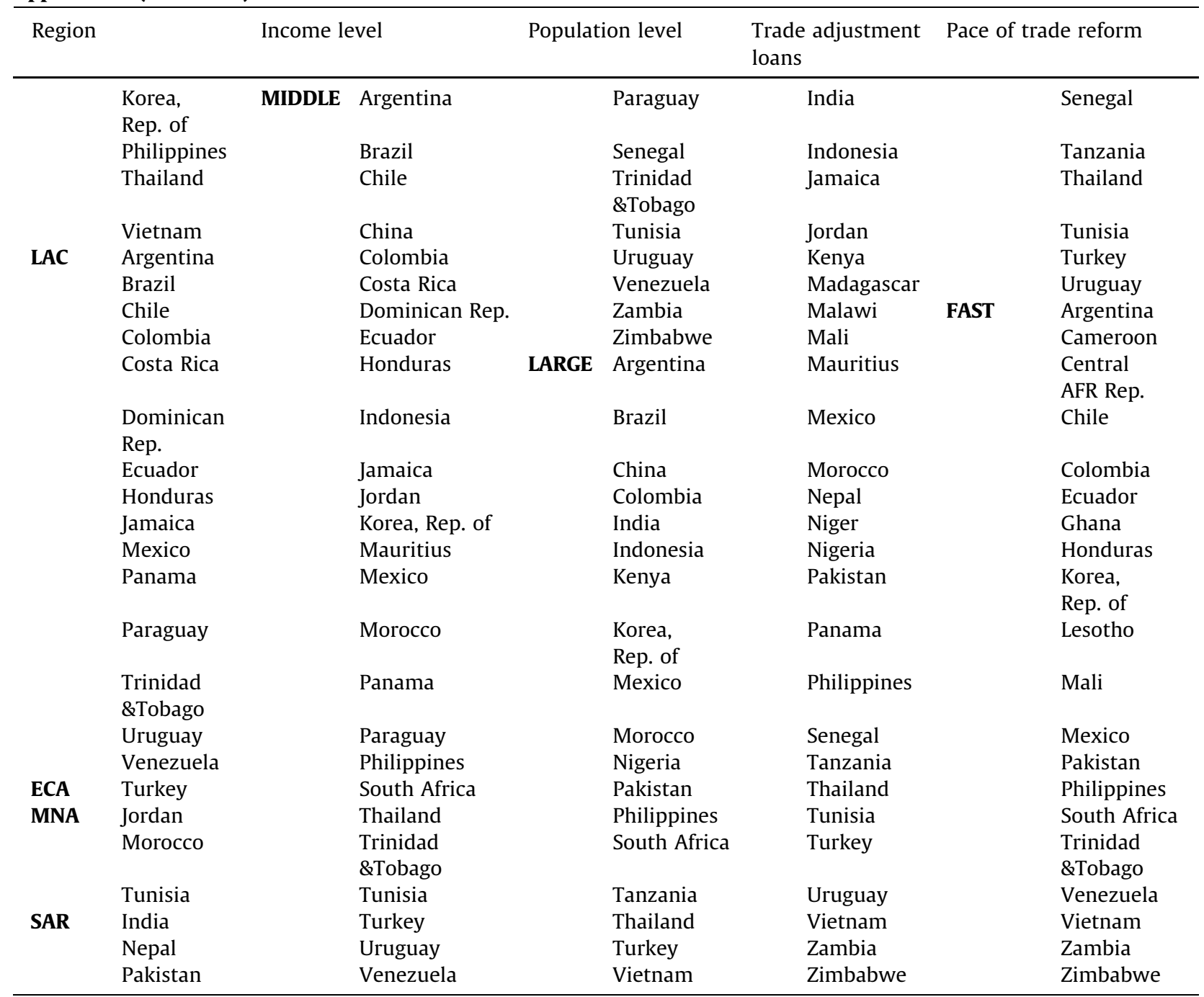

\section{References}

Atoyan, Ruben, Conway, Patrick, 2006. Evaluating the impact of IMF programs: a comparison of matching and instrumentalvariable estimators. Review of International Organizations 1 (2) 99-124.

Berg, A., Ostry, J.D., Zettelmeyer, J., 2012. What makes growth sustained. Journal of Development Economics 98 (2) $149-166$. Bolaky, B., Freund, C., 2004. Trade, Regulations, and Growth. Policy Research Working Paper No. WPS3255. The World Bank, Washington, D.C.

Cadot, O., Fernandes, A.M., Gourdon, J., Mattoo, A., 2011. Where to Spend the Next Million? Applying Trade Impact Evaluation to Trade Assistance. IBRD/World Bank.

Calderón, C., Servén, L., 2004. The Effects of Infrastructure Development on Growth and Income Distribution. Policy Research Working Paper No. WPS3400. The World Bank, Washington, DC.

Collier, P., Greenaway, D., Gunning, J.W., 1999. Evaluating trade liberalization: a methodological framework. In: Ademola Oyejide, T., Elbadawi, I., Collier, P. (Eds.), Regional Integration and Trade Liberalization in Sub-Saharan Africa. Vol. 1: Framework, Issues and Methodological Perspectives. St Martin's Press, Basingstoke and London: Macmillan and New York.

Collier, P., Hoeffler, A., Soderbom, M., 2004. On the duration of civil war. Journal of Peace Research 41 (3) 253-273.

Conway, P., 1994. IMF lending programs: participation and impact. Journal of Development Economics 45 (2) $365-391$.

Conway, P., 1998. Evaluating Fund Programs: Methodology and Empirical Estimates, unpublished.

Deaton, A., 2010. Instruments, randomization, and learning about development. Journal of Economic Literature 48 (2) $424-455$. Dollar, D., Kraay, A., 2004. Trade, growth, and poverty. Economic Journal 114 (493) F22-F49.

Edwards, S., 1998. Openness, productivity and growth: what do we really know? Economic Journal 108 (447) $383-398$.

Faini, R., de Melo, J., Senhadji-Semlali, A., Stanton, J., 1991. Growth-oriented adjustment programs: a statistical analysis. World Development 19 (8) 957-967.

Frankel, J.A., Romer, D., 1999. Does trade cause growth? American Economic Review 89 (3) 379-399.

Goldstein, M., Montiel, P., 1986. Evaluating fund stabilization programs with multicountry data: some methodological pitfalls. IMF Staff Papers 33 (2) 304-344. 
Greenaway, D., Morgan, W., Wright, P., 2002. Trade liberalization and growth in developing countries. Journal of Development Economics 67, 229-244.

Heckman, J.J., 1979. Sample selection bias as a specification error. Econometrica 47 (1) 153-161.

Kaufmann, D., Kraay, A., Mastruzzi, M., 2004. Governance Matters III: Governance Indicators for 1996-2002. Policy Research Working Paper No. WPS3106. The World Bank, Washington, D.C.

Khan, M.S., Montiel, P.J., 1989. Growth-oriented adjustment programs: a conceptual framework. IMF Staff Papers, Palgrave Macmillan 36 (2) 279-306.

Krueger, Anne O., 1998. Why trade liberalization is good for growth. Economic Journal 108 (450) 1513-1522.

Looi Kee, H., Nicita, A., Olarreaga, M., 2009. Estimating trade restrictiveness indices. Economic Journal 119 (534) $172-199$.

Mundlak, Y., 1978. On the pooling of time series and cross section data. Econometrica 46 (1) 69-85.

Jinjarak, Y., Salinas, G., 2005. Chapter 4: Outcomes and Results.' in Assessing World Bank support for trade, 1987-2004: an IEG evaluation, Tsikata, Y.M. (Ed.), the World Bank InfoShop, pp. 31-47, ISBN: 978-0-8213-6591-5.

Rajan, R.G., Subramanian, A., 2008. Aid and growth: what does the cross-country evidence really show. Review of Economics and Statistics 90 (4) 643-665.

Rodrik, D., 2007. Credibility of trade reform-a policy maker's guide. World Economy 12 (1) 1-16.

Rodriguez, F., Rodrik, D., 2000. Trade policy and economic growth: A skeptic's guide. In: Bernanke, B.S., Rogoff, K. (Eds.), NBER Macroeconomics Annual, vol. 15. MIT Press, pp. 261-338.

Sachs, J.D., Warner, A.M., 1995. Economic convergence and economic policies. In: Brainard, W., Perry, G. (Eds.), Brooking Papers on Economic Activity 1. pp. 108-118.

Sala-I-Martin, X.X., 1997. I just ran two million regressions. American Economic Review 87 (2) 178-183.

Santos-Paulino, A., Thirlwall, T., 2004. The impact of trade liberalization on exports, imports and the balance of payments of developing countries. The Economic Journal 114 (493) F50-F72.

Wacziarg, R., Welch, K.H., 2008. Trade liberalization and growth: new evidence. World Bank Economic Review 22 (2) $187-231$.

Wei, S.-J., Zhang, Z., 2010. Do external interventions work? The case of trade reform conditions in IMF supported programs. Journal of Development Economics 92 (1) 71-81.

Wooldridge, J.M., 2010. Econometric Analysis of Cross Section and Panel Data. The MIT Press, Cambridge, MA. 